\title{
Gender Inequality in Basic Education in the Northern Region of Ghana: Household and Contextual Factors in Perspectives
}

\author{
Eliasu Alhassan \\ Department of Social Political \& Historical Studies \\ University for Development Studies \\ Email: eliasua@yahoo.com \\ and \\ Felicia Safoa Odame \\ Department of Social Political \& Historical Studies \\ University for Development Studies \\ Email: feliasiedu@yahoo.com \\ DOI//http://dx.doi.org/10.4314/gjdsv12i1\&2.8
}

\begin{abstract}
The Government of Ghana has implemented a number of policies towards achieving quality and gender equality in basic schools in Ghana. These policies include the School Feeding Programme, Capitation Grant and recently the provision of Free School Uniform to pupils in basic schools. This paper examines household factors as well as contextual factors that militate against the effort of government in achieving quality and gender equality in enrolment and attendance in basic schools in the the Northern Region of Ghana. Household questionnaire, interview guides were used to obtain the primary data while the secondary data were sourced via the internet, published dissertations and journals. Socio-economic factors such as the high cost associated with girls' education, availability of household resources, poverty and high number of market days served as barriers to gender equality in basic education in the Northern Region of Ghana. Socio-cultural practices such as boy child preference, polygyny, fostering, early marriage, menstruation and attendance at festival celebrations are key factors militating against quality and gender equality in basic schools in the region. Vigorous sensitization on the negative effects of these socio-cultural factors by the government and NGOs and the removal of all forms of levies in basic schools as well as strict enforcement of the Free Compulsory Basic Education policy by the government would go a long way to improve access to basic education in the Northern Region of Ghana.
\end{abstract}


Keywords: Equality, Basic Education, Gender, Enrolment, Attendance

\section{INTRODUCTION}

Gender equality, quality and the effects of socio economic and socio cultural differences in the provision of learning opportunities are some of the major concerns in education development in many developing countries. One particular concern is unequal or the disadvantaged position of women as compared to men and by extension girls as compared to boys in basic education participation in terms of enrolment and school attendance. According to the goals of Education for All (EFA) and Millennium Development Goals (MDGs), many countries were faced with challenges of eliminating gender inequality in basic education by 2010 and are still not sure of achieving gender equality in enrolment and attendance in basic education by 2015 (UN Report, 2012).

To achieve this target, informed strategies to improve the participation of both male and female citizens in various socioeconomic activities including education are necessary. In most developing countries, gender differentials in education are more pronounced in terms of participation and internal efficiency and in cognitive performance with girls being the most affected. While enrolment rates to some extent do not differ greatly, more boys than girls complete schooling, especially at the basic school (Kane, 2004).

The impact of gender and home-based factors on enrolment and attendance cannot be over emphasized. Policy initiatives towards achieving gender equality in enrolment and attendance have included abolition of all forms of fees charged at the basic levels. When Kenya abolished all fees at the primary level, the primary gross enrolment reached 7.2 million pupils (48.6\% female) having risen from 5.4 million pupils in 1989 to $56.3 \%$ in 2010. Interventions aimed at promoting girls education include taking affirmative action in support of girl-child education; expansion and improvement of classrooms, boarding facilities and water and sanitation facilities to create conducive and gender responsive environments particularly in arid and semi-arid lands and providing support to nonformal education institutions (UN Report, 2012).

Despite the impressive gains in access to education, issues of gender equality and participation in enrolment and attendance, progression and performance at the basic education level require further analysis. Customs and circumstance at home lead to a range of cultural practices which cause differences in schooling outcomes. For instance, at the time of the 2010 population census in Ghana, 36 percent of all males aged 6 and above were attending school compared to 38 percent of females (GSS, 2012). More glaring gender differences were observed among the population who never attended school. Female participation in education dropped from 38 in 2010 to 24 percent in 2012, while that of males dropped from 18 percent in 2010 to 14 percent in 2012 (GSS, 2012).The gender gap had also narrowed during these years implying that participation rates are close to gender equality. Therefore, it is important to understand the underlying factors contributing to the differences (related to gender and socio-economic as well as socio-cultural factors 
affecting schooling especially at the basic level) in order to provide reliable data and empirical evidence for policy formulation (Allen, 1994).

The paper is structured around five thematic areas one of which is the introduction which discusses the Millennium Development Goals and the goals of Education for All (EFA) to achieve gender parity in enrolment and attendance by 2015. Theoretical bases for gender inequality especially, the equity and equality perspectives by the United Nations Organizations are examined. The paper further explains the methodology of the study thus, the processes and procedures involved in sampling data collection and data handling. The key findings and discussions of the socio-cultural and contextual challenges of gender equality in basic schools are discussed. The socio-economic challenges as well as the conclusion and recommendations are discussed in the tail end of the paper.

\section{THEORETICAL FRAMEWORK}

International debates and practices on gender equality in basic education during the past decade have crystallized into two different mutually complementary perspectives: the equity perspective and the equality perspective. The difference according to the UNO (2012) is that while the equity perspectives deals with the process of being fair to women and to ensure fairness, strategies and measures must often be available to compensate women's historical and social disadvantage that prevent women and men from otherwise operating on a level playing field. Gender equality perspective requires equal enjoyment by women and men of social-value goods, access, opportunities, resources and rewards. The current paper concentrates on the equality perspective.

The equality perspective goes beyond access and quality issues in basic education and beyond training women for employment and income generation opportunities. It recognizes that gender is a socio-cultural construct and underscores the social relations between men and women in which women are systematically subordinated. Advocates of education for gender equality argue that structural transformations are needed in order to end discriminatory practices based on gender. Basic education for equality thus entails the necessity of empowering women by giving them a range of socio-cultural competencies and tools beyond the narrow conceptualization of reading and writing skills. According to diverse studies undertaken by Hamburg (2012), empowerment in education involves several dimensions: a cognitive dimension or women's awareness and understanding of their conditions and causes of subordination. A psychological dimension, or women's selfconfidence and self-esteem; an economic dimension or women's ability to access resources to engage in productive activities and to take autonomous decisions and a political dimension or women's ability to set their own agenda to negotiate, lead and organize for challenging oppression and changing conditions (OXFAM, 2005).

Education for gender equality aims to transform gender relations so that both women and men enjoy the same opportunities to achieve their potential. The challenge of achieving quality and gender equality raises important questions about the education of boys and 
men as well as girls and women. The attitudes and behaviour of boys and men along with girls and women within the larger societal context need to be examined to change gender bias and stereotyped view on the roles of men and women. Being committed to promoting gender equality, UNESCO (2012) did not accept the arguments that insist on a male-female dichotomy - attributing characteristics to women and men by virtue of their sex. UNESCO believes that this line of argumentation is non-productive and does not lead the way forward to gender equality. Social structures that reproduce gender inequality should be addressed by acknowledging the complexity of social and cultural norms.

Roemer (1998) argued that gender bias and sexist stereotypes are internalized by boys and men, and girls and women alike through socialization process. Thus social structures that uphold gender inequality continue to exist. The basic education setting must provide an enabling environment to address and prevent gender-biased attitudes and practices from taking hold. Basic education that promotes gender equality requires a holistic gender-sensitive approach that upholds mutual respect between boys and girls and between men and women. The situations of both boys and girls must be addressed through gender analysis that examines both the realities and causes of inequalities. The responses for addressing inequality may vary in different contexts. However, through basic education, equitable and creative solutions must be sought to bring girls and women to an equal playing field with boys and men and to realize an all-inclusive learning and social system. Schleicher (2007) noted that gender equality approach takes into consideration the fact that women do not constitute a homogeneous population group and that there are discriminatory social and economic elements within the category of women in the households. Addressing questions of poverty are an intrinsic element of gender equality in basic education.

Dolphyne (1991) argued that all these forms of inequalities in the society have much to do with Antonio Gramsci's theory of hegemony that is a large number of people agree to believe the same things and that they agree not because they are coerced or tortured into it but because their consent is mobilized. In other words, they come to believe through socialization that their particular system especially inequality among individuals and among men and women is natural and the only way to live and that they will defend their cultural way of living to the death. The beliefs of a culture always operate to suit the interests of those who hold power. However, when one idea no longer serves an economic or social purpose that suits the powerful the belief changes therefore the inequality among males and females benefit those in power positions in the society.

Cultural hegemony again works very much on Parson's theory of functionalism and Durkheim's notion of social facts. What this means is that Parson's binary system of gender that is male-female dichotomy serves a function in the society. It is the principle that keeps society in order and while it may not be a natural law it has certainly become a social fact - beliefs that the majority of people in the society believe to be true. Durkheim introduced the notion that social facts became just as natural laws; for example, gravity kept us anchored to the earth is a natural law but all people are automatically masculine 
or feminine depending on their genitalia is a social fact. The sky is blue is a natural law and all people will be heterosexual based on the genitals they are born with remains a social facts. Hegemony is the only thing perpetuating them therefore inequality in the society is a natural law hence it is beyond human control.

Furthermore, the culture - nature and nature - nurture debates seem to continue in the society today. The perceptions that gender inequality caused by our culture and being a natural phenomenon still continue in the society. It has never been satisfactorily reconciled that our society can say with pride that we have defeated nature and condemns other people for being unnatural by defying notions of gender inequality.

\section{METHODOLOGY}

The population of the Northern Region was 2,479,461 according to the Ghana Statistical Service (2012). Five cases from the major ethnic groups in the region (Dagomba, Mamprusi, Gonja, Nanumba and Konkomba would have been enough for fair representation but the law of representation states that the larger the sampling size the more representative it is in the population (Mugender \& Mugender, 1999).

The study was descriptive in nature. This allowed the use of data to explain household as well as contextual factors affecting gender inequality in basic schools in the Northern Region of Ghana. Probability and non-probability sampling techniques were used the probability techniques included simple random sampling which was used to select the districts and in many instances the communities. The non-probability techniques included purposive sampling which was used to select households with both male and female children while convenient sampling was used to select the headteachers and children out of school. Household heads, school pupils and headteachers were the target population and data were sourced from these categories of respondents through the use of semi-structured interview guides and questionnaires.

The study used secondary data from published dissertations, journals and the internet. In all a total of two hundred and forty-eight questionnaires were used and these included one hundred and fifty two household heads and ninety-six school pupils. The classes were put into clusters and with the assistance of the headteachers these pupils were interviewed. Schools were purposively selected including schools which benefit from the School Feeding Programme and thirty headteachers of the selected schools were interviewed.Qualitative and quantitative data were obtained and in many instances the qualitative data were organised in to themes and analysed while percentages and charts were used to analyse the quantitative data with the help of the Statistical Package for Social Scientists (SPSS). 


\section{FINDINGS}

\section{Household and Contextual Challenges}

The composition of households in the Northern Region remains largely traditional and the families are extended families except in Christian households where nuclear families dominate even among the urban dwellers. Males dominated the responses in the households. They are the heads of their families and the decision to send children to school or withdraw them from school is usually taken by men. Female-headed households do exist in the region. These heads were seen mostly from Savelugu-Nanton District, East Gonja and Tamale Metropolis. Households in which both spouses live, men are the heads of the families but where the husband is not present the mature male son becomes the head of the family. Female-headed households are uncommon in the region and when it comes to the enrolment of their children they take the decision in favour of the male child which widens the gender inequality gap in enrolment. The study found that Christian households enrolled both their male and female children in school and allows them to attend school. Out of six Christian households visited five households had all their children in school except one household head who explained that his children are not in school because of his inability to pay fees that are charged by the school authorities. It was noted that girl-child education is part of the Christian faith and that Christianity was introduced in Ghana alongside education. Therefore, there is no point in Christian's life where Christian parents will deny their daughters education.

Islam does not discourage girls' education, it only prefers the male children to be more educated than the female children because of the fact that women marry out of the households, therefore investing more in them to acquire higher education means investing in the prospective husband. Out of the a hundred and six households visited ninety household heads had their children enrolled in school and sixteen household heads did not enrol their girls in school. Muslims prefer to educate the male-child rather than the female-child. African Traditional Religion (ATR) has seen the need to educate female children in the Ghanaian society today. Although, formal education in the past was seen as a threat to the beliefs and practices of the African Traditional Religion (ATR) in the Northern Region of Ghana but this threat is now fading away. This was evidenced when out of forty traditional households only three households did not have their children in school. It was again noted that boys were enrolled in school and allowed to attend more than girls. The question of inequality between the girl-child and the boy-child in enrolment and attendance in education should not even arise in African Traditional Religion at all (ATR), being the oldest religion in Ghana, men and women had their roles to play in the society and that formal education for girls is a necessary evil (Murshid, 1996).

Murshid (1996) argued that despite the broadly equalizing influence of recent development on educational attainment of boys and girls, a number of historical influences can result in the persistent inequality in enrolment and attendance in basic education in Christianity, Islam and ATR. The authors explained that higher educational 
attainment among Christians have been attributed to the acceptance of secular education while majority of the Muslims still prefer education in Arabic because Arabic education started before secular education. These divergent historical paths in secular education have also led to the Christians being better represented in service-sector occupations such judiciary services, parliamentary services and industrial services.

In many districts in the Northern Region such as Tamale,Yendi, Damongo Gushegu and Bole, Arabic schools still exist, especially in the urban and the peri-urban areas where many parents still enrol their girls and make a lot of investments in the growth of "madrasahs" (Arabic schools) as a way of increasing access to basic school among the disadvantage Muslims. Though, the inequality in school enrolment still exists in these schools the trend has changed as the current study revealed. More girls are now being enrolled at the primary school level than boys in the Arabic schools but more males are allowed to pursue higher education than the females. The situation is different at the JHS level where the inequality in enrolment is still in favour of the boys as reported by the Federation of Women Educationist (2001).

There was a wide variation in the proportion of the population who are married and those unmarried in the region. Marital statuses of the respondents were measured on the nominal scale specifying the categories of the statuses and the sampling was purposive. This may not reflect exactly what pertains in other districts because the questions were restricted to only households with both male and female children. Those who were married were more than those who were not married. The unmarried but with children were not respected in their communities as compared to the married with children, especially when it comes to decision making in the communities. Children of those who were not legally married were teased in school which caused some parents to withdraw their children from school. Both girls and boys were affected; but the girls were affected more than the boys.

Marriage is an important institution and cherished by the people of the Northern Region of Ghana. When couples are legally married to each other it has positive effects on their children schooling, especially girls schooling. Those who are not legally married in the region are unhappy about their situation; their children too are unhappy in schools which sometimes discourage the children from attending school regularly in the Northern Region of Ghana.

The 1985 Marriage Ordinance Act 127 of Ghana makes the legal age for marriage as 18 for girls and 21 for boys respectively .The amendment to this act 1998 ( Act 560) which was in line with the 19992 constitution of Ghana placed the minimum age for marriage of all categories to 18 years. Religious and customary practices in Northern Region of Ghana lead to both early betrothal that is at birth and marriage of girls before eighteen years. Where it can be proven that the girl's consent to an early customary or religious marriage was absent; a prosecution for forcible marriage can be carried out. Many females do not know that they have the right to refuse early marriage; many feel compelled to 
cohabit with a man by circumstances such as poverty. Public education is geared towards educating families about the health hazards of early marriage to the girls and encouraging parents/guardians to allow girls to go to school and spend more years in school before marrying and starting families Junge (1988) cited in Odaga and Haneveld (1995). Girls' marrying before the age of sixteen years is a common practice in the region as compared to the boys, and this negatively affects girls' school attendance more than the boys. In almost all the rural areas, girls and boys who were 16 years were seen with their spouses. Indeed, some girls in this category were seen nursing babies and they were out of school. One of the girls who got married before the age of sixteen years and stopped schooling explained in an exclusive interview:

"I was living with my senior sister and her husband in Tamale. One day my mother asked my sister to let me come to the village. Immediately I arrived in the village, the following day, my mother told me that my father has decided that I got married to a husband whom I have never known before. I had no option than to agree. The following week, the husband's father came to our house and begged my hand in marriage and that resulted to my current situation. I was not able to continue my education because by then, I was in class six in Tamale. When I got married, my husband said that I cannot attend school again now that I am married" (Field work, August 2012).

Early marriage may end a girl's education; she may not be able to combine her studies with matrimonial task she may even find it difficult to attend school and learn. All these factors widen the inequality in school attendance between her and her male counterparts.

The evidence above was supported by Junge (1988) cited in Odaga and Haneveld (1995) when the author noted that actions including early marriage compete with school for girls in most societies in Africa and that the age at which girls marry make marriage an important institution in the society. It was supported by El-sanabary (2001) when the author also explained that the higher bride-wealth paid for educated girls is one of the reasons that parents in Zaire send their daughters to school. In the Northern Region of Ghana, girls in the school - going ages are given out for marriage at tender ages. Some are betrothed at the age of two years and this leads to non-enrolment of girls in the in schools. If even enrolled, they drop out because of pressures from their families to go and stay with their husbands. Ahamed's (2000) study in Ethiopia confirmed that 20 percent of primary school girls were either promised marriage or divorced. In this case, both girls and boys were affected. The situation in Ethiopia is not so different from the current study in the Northern Region of Ghana; the only difference is that child betrothal in the Northern Region was not the most common reason for non-enrolment of girls in schools as reported in Ethiopia.

Another socio-cultural factor that affects gender equality in enrolment and attendance is the practice of polygyny by the people of the Northern Region. According Robertson 
and Berger (2004) the practice of polygyny has its roots from the ATR. The study found that polygyny is widely practiced in the Northern Region and negatively affects children's education, especially school enrolment and attendance. When Islam was introduced as a religion in the region it gave credence to the practice of polygyny. Islam has restricted its followers to marry up to four wives. On the contrary, African Traditional Religion encourages a man to marry more than four wives. Exclusive interviews with two respondents in Buya in East Gonja District and Kuyilli in Zabzugu Tatale District confirmed how polygyny affect girls' enrollment and attendance in education. The following narrations were given by one of the Muslims interviewees living in the community mentioned above. He had four wives with fourteen children nine girls and five boys. Out of the nine girls only two are attending school in Tamale the rest of the children only assist their parents in the market and on the farm. The two girls who attend school live with the interviewee's junior brother in Tamale. The interviewee said:

"I live with my four wives and twelve children. My only source of income is what I get from the farm. I need to feed my wives and the children at all times. So, if I send my children to school, who is going to assist me again on the farm? Again, he added, I regret that my father did not send me to school and it was the same problem he faced when I was young... my inability to send my children to school is as a result of the number of wives I have, it is Islamic teaching that I cannot refuse" (Field work, August 2012).

Majority of Muslims throughout the Northern Region of Ghana practise polygyny and this is often cited as one of the many reasons why gender disparity in enrolment and attendance in basic schools still exists in the Northern Region of Ghana, especially in the Muslim dominated areas. Muslims in the region cherish polygyny to the extent that those with only one wife are considered as bachelors. The practice of polygyny though a cultural phenomenon has support in the Islamic religion. The current results on polygyny in the Northern Region show that there are still Muslims in the region who do not still enrol their daughters' and allow them to attend school and this violates the saying of the prophet Mohammed: "Seeking of knowledge is compulsory upon both men and women."

When polygynous households were interviewed it was found that 57.9 percent of the households had two children are in school, 18.1 percent had three are in school, 10.4 percent had four boys attending school and 13.6 percent had one child attending school. Confirming results, Robertson and Berger (2004) explained that women in polygynous families bear the large burden of educating their children (both boys and girls). The author added that the girl-child stands at a disadvantage when it comes to which child should be withdrawn from school in these families. This situation is not different in the Northern part of Ghana. Relating the effects of polygyny to fostering, both the girl-child and the boy-child in urban areas stand at a disadvantage. Both girls and boys are given to other relatives in the urban area to take care of. This practice is very common in the Northern Region of Ghana. 
Foster mothers and fathers in many cases do not allow their foster children to attend school.

The girls tend to be house-helps in the urban areas and are not allowed to attend school. It was difficult getting out-of-school children to interview. An interviewee who was out of school and currently staying with her aunt in Saboba said:

"I stayed with my father's sister for almost seven years now. I stopped schooling when I was in class three because my aunt said she has no money to let me continue my education, but I noticed that my aunt's first child is in secondary school in Tamale and her other two children are in Yendi with their father attending school. When my mother visited us in Saboba I told her and she said she would discuss it with my aunt. Since then I have not heard anything again" (Field work, August 2012).

Darkwah (2010) explained that fostering is an old cultural practice in Ghana and that many Ghanaians are raised by other relatives but the practice does not augur well for girls since most of them are denied access to education. As to whether the parents in the rural areas are aware of the situation of their daughters in the urban areas in relation to their education, 8o percent of the household heads explained that they are aware. However, they noted that taking their daughters back may create disunity among the extended family systems. They further explained that most of them went through the same fate being raised by other relatives.

Menstruation is a natural event experienced by women during certain times of their lives. Yet, it is often a topic which is seldom and openly discussed. Many girls lack sufficient or accurate knowledge about menstruation. The parents often have misunderstanding and mistaken beliefs. Many women do not understand the purpose of menstruation and what happens in their bodies during menstruation. They do not attend school during this period because of cramps that is associated with menstruation. Another female interviewee said: "I do not attend School at all when I am menstruating. I experience painful menstruation all the time so my parents are aware of my situation. At times, I do not attend school three days during menstruation" (Field work, August 2012).

Another important factor is the performance of funeral rites, one of the most solemn events in life when a loved one dies. It is therefore not surprising that in many communities in Ghana funeral rites are performed in honour of the departed soul and during the performance these rites pupils in both the primary and JHS schools do not attend school because they are asked by their parents to assist the bereaved families in cooking, fetching of water and firewood. This was found in the Muslim communities in the Northern Region. In this case, the facts from the school registers showed that the girls are affected more than the boys in school attendance.

The researcher witnessed funeral rites in Kpatiga and Wundua communities both were Muslim Communities on Monday and Thursday. It was observed that the schools recorded 
low attendance of pupils, especially girls' attendance as compared to the boys. The registers of Kpatiga JHS in Gushegu Karaga District and Wundua Primary School in East Mamprusi District of the two days were cross-checked and out of the total of 2,150 weekly attendances of both boys and girls, the girls had a total of 760 attendances for the week while the boys had a total 1,200 attendances for the two schools.

The study compared the total attendance from the registers of the two schools in Saboba/ Chereponi (Gbemja Primary) and West Mamprusi (Duu Primary) within the week in which no funeral rites were performed in the two communities and realized that there was disparity in school attendance between the boys and the girls. Out of a total of 2,140 school days, the girls recorded 955 total attendances while the boys recorded 1,185 total attendances. Though there was still disparity in the week of non-funeral rites, the disparity gap was wide in the week of the funeral rites in favour of the boy-child. On these days, it was again observed that the girls were asked by their parents to fetch water and firewood for the bereaved families while some boys absented themselves when there was drumming and dancing. The headteachers corroborated the findings during the interviews. Eighty-nine percent of the headteachers explained that during the performance of funerals in their communities about 70-80 percent of girls do not attend school. They are asked by their families to go and assist the house where the funeral is being performed in cooking, fetching of water and firewood.

Festivals in the Northern Region occur within the whole year and are used as a means to remember the ancestors. They are also held to purify the community and allow its people to go into the new-year with hope. "Damba" festival is not celebrated by the Christian households but Christians who belong to the ethnic groups mentioned earlier celebrate the "Bugum" or Fire Festival. The celebrations of these festivals involve a display of a colourful tradition of the people in the region. The study further revealed that during the celebration of these festivals both boys and girls do not attend school; the girls are more affected than the boys. Checking from the school registers, it was observed that the "Bugum" Festival only lasts for one day. The school registers for 2010/2011 academic year of the various schools revealed that the days for the "Bugum" and the "Damba" (including the "Somo" and the "Naa Damba") for the year were not marked.

The average attendance for both boys and girls in Gushegu/ Karaga, Bimbila, Bole and Tolun Kumbungu decreased by four days, when compared with the 2009/2010 as well as 2008/2009 academic years. The girls' attendance was far below that of the boys therefore disparity in attendance was in favour of the boys (1,432 and 2,134 respectively) and if this trend continues the target of equality in attendance will not be achieved by 2015 in the region.

The "unofficial" holidays of these festivals disrupt their academic calendar since they do not know the exact dates of the festivals. The headteachers further explained that even the death of an important person in the community calls for "unofficial" holiday because both boys and girls are affected in this regard. Additionally, the study found that during 
the enskinment of regents or chiefs, attendance of the girl - child is poor as compared with the boy-child. The headteachers explained the reasons for this phenomenon by stressing that during this time families asked their girls to cook fetch water and firewood for the occasion. Evidently, this widens the disparity in attendance between the boys and girls in the basic schools in the Northern Region of Ghana. In a response to a question relating to unofficial holidays during this period, District Directors said that it is a tradition and that they allow it because they do not want to have problems with the community chiefs since they are also partners in education. Implicitly, festivals though a cultural practices negatively affect pupils' attendance to school. The effects are more on the girls than the boys because girls do not attend school on the celebration days and this creates gender disparity in favour of boys in attendance to basic schools in the region.

As part of the household challenges, socio-economic factors that affect gender inequality in enrolment and attendance in basic schools in the Northern Region of Ghana include the occupation of the households, household heads income, cost associated with boys and girls education, household chores, market days and the type of work both girls and boys do at home. The occupation of the household heads was related to the income of the household. Households' earn their income through the work they do. Households with low incomes are unable to meet the cost of educating their children, especially the female children. One of them said: "I do not earn much at the end of the month; sometimes the income from the sales of my farm produce is so low that I am unable to meet the cost of educating my children" (Field work, August 2012).

This point is supported by the study of El-sanabary (2001). The author noted that girls from the middle - incomes and high - income families in Africa are more likely to be enrolled and remain in school as compared with the girls from low income families. It was observed in the households that parents from rural areas in the Northern Region are unable to meet the cost of educating both their girls and boys. Some of the children were seen in school with torn uniforms which make them feel uncomfortable among their peers in class and they sometimes discourage them from attending school. Even if they even attend, they feel reluctant to participate in class and other school activities. Household heads prefer the male child to go to school when the household heads' income is low. The boy - child will not get married and move out to stay with another family. So investing in him could bring good returns to the household in future.

Household heads spend yearly on females' basic schooling more than males' schooling (GHC 570.00 and GHc 420.00 respectively) and the situation where household income is low it negatively affects females' enrolment and attendance. This creates disparity, especially in attendance in favour of the male-child. Mathew (2000) discussed many factors which combine to spell an end to the education of the girl-child; poverty, cost of voluntary contribution, school uniform, books and transport fares, which can even make free education expensive. This widens the disparity in enrolment between boys and girls in the basic schools in the Northern Region of Ghana. 
Specialisation of tasks is traditionally associated with gender. Girls in households are seen as future mothers, care takers and domestic managers while boys in the households are seen as future income earners. The single most important factor that creates inequality in attendance among pupils in basic schools in the Northern Region of Ghana is the household chores. The household chores included sweeping, fetching of water, helping mothers to cook, washing of bowls and clothing and taking care of young siblings. All the pupils participate in all sort of household work except that the household chores dominate in the work girls do at home. It was observed in the communities that there were boys seen herding livestock at the outskirts of the rural communities and some girls were also seen assisting their mothers in buying and selling during market days. For mothers especially, allowing their girls to attend school means more domestic responsibilities for themselves, which indirectly affect their income earning ability. The boys do more work on the farm as compared to the girls.

OXFAM (2005) studies in Zambia, Kenya, Mali, Cameroun and Uganda showed that both girls and boys are equally involved in household chores and that the enrolment and attendance of boys are greatly affected by this burden. The situation in those countries is different from the situation in the Northern Region of Ghana. It can be recognized that though some boys do engage in household chores, the degree of engagement is not equal to the girls as claimed by OXFAM (2005). Mathew (2000) supported the current study by noting that household chores have added to many factors that can combined to spell out the early end of girls' education. According to the author, poor families consider how much a daughter can help in cleaning, cooking, collecting fire wood and water as well as looking after young siblings and how little opportunity there will be for her to get a paying job if she is educated. The household chores are preferred to allowing the daughter to attend school and allowing her to attend school. The Mathew (2000) further added that even if the girl-child is enrolled, the burden of domestic chores stands in a way of her educational progress.

Many girls do not attend school on certain market days in the Northern Region of Ghana. They go to the market to sell their parents' wares. These market days were the Tamale Market Days, Techiman Market Days in some cases and the Village or Community Market Days. These market days are patronized by the people of the Northern Region of Ghana. The result from the school registers when cross-checked showed that girls absent themselves from school more than the boys. It was observed that out of the total number of market days, the boys recorded a total of 211 market days while the girls recorded 110 market days in a year. It was observed that the disparity in attendance favored the boys, 3,597 days for all boys and 2,528 for girls. If this trend continues unchecked, equality in attendance will be a mirage by 2015. The following chart shows weekly attendance by girls as a result of market days. 


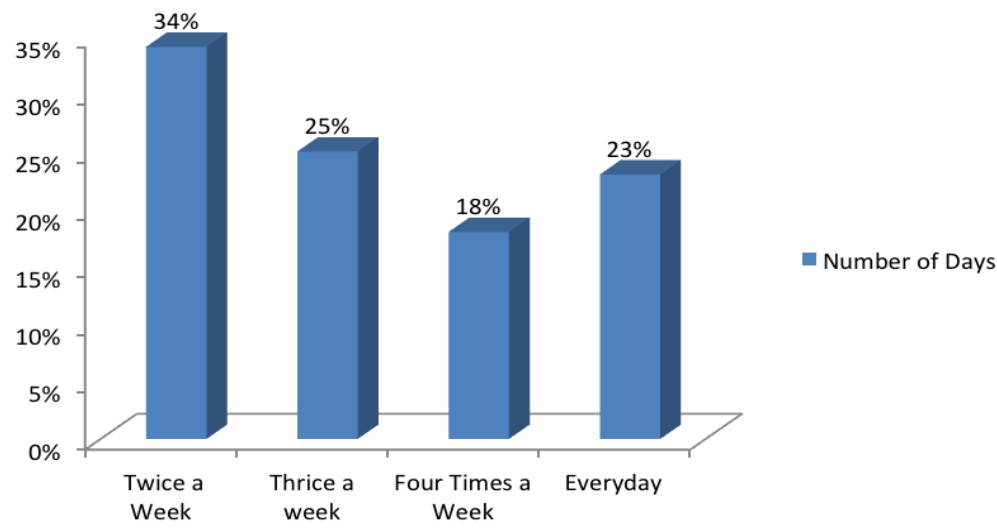

Figure: 1 Number of days girls attends school in a week as a result of market days Source: Field Survey, August 2012

Figure 1 shows that 34 percent of the girls attend school twice in a week, 25 percent said they attend school thrice in a week, 18 percent of the girls said they attend school four times in a week and 23 percent said they attend everyday even during market days. These responses further depict gender disparity in attendance in basic schools in the Northern Region. In comparison, the study did not find any situation where the boys are asked by their parents to sell wares at any market day. The boys explained that they do not go to the market to sell anything with their parents and it is their sisters who go with their mothers. During the interview with the headteachers, they explained that the situation in which the girl-child has found herself in the Northern Region is considered excessive exploitation and it is harmful and detrimental to her education and development. It is also a hindrance to her preparation to adult roles and responsibilities.

\section{CONCLUSION}

There has been progress in school enrolment for both girls and boys in recent times in the Northern Region especially between 2010 and 2012 academic years yet, inequality in educational opportunities for girls and boys increased from primary to Junior High level in 2012. The gender gap is so pronounced that it will be very difficult for the government of Ghana to meet the target of equality in enrolment and attendance by 2015. Measures including balancing the enrolment gaps especially at the beginning of school cycles to prevent early dropout of girls and also a curriculum which does not replicate stereotyped gender roles would effectively bridge the gap. These should be adopted by all districts in the region. 
Gender equality in education requires gender mainstreaming initiatives in the entire sector. In addition, special interventions targeting women and girls can make up for serious gaps. In the process of planning education programmes it can be useful to carry out a sector gender analysis to identify differences between boys and girls with implications for school enrolment and attendance, Prospects for tertiary and vocational training and use of educational skills on the formal and informal labour markets can also inform a gender sector analysis in education. Gender inequality emerges at different points through the education system. In many countries, gender gaps appear on the first day of school.

Three quarters of the countries including Ghana that have not achieved gender equality in enrolment at the primary level enrol more boys than girls at the start of the school cycle. Unless this imbalance is corrected the inevitable result is a permanent gender inequality in primary school. The socio - cultural-factors are more pronounced in the rural households than socio-economic factors. Although both factors have negatively affected gender inequality in basic education in the region the socio-cultural factors are important to address than the socio-economic factors since these are embedded in the culture.

Vigorous sensitization on the negative effects of these socio-cultural factors on both the girls and the boys basic education as well as remove all forms of levy in the basic schools to enable parents enroll their girls would ensure equal access to basic education. A subsidiary policy that would enforce the compulsory aspect of the free Compulsory Basic Education such that sanctions can be applied to parents who often refuse to enroll their children would also ensure that all children of school going age are enrolled in school in the Northern Region of Ghana.

\section{References}

Aggarwal, J. C. (2005). Teacher and education in a development society. Accra: Vikas Publishing House LMT.

Alhassan, E. and Aseidu, F. S. (2013). The challenges of adolescent girls' sexual maturation to educational parity in Northern Ghana. Journal of Public Policy and Administration Research. Vol. 3 No. 8, pp. 43-54.

Alhassan, E. (2010). Determinants of girl-child education in Gushegu Karaga district of the Northern Region of Ghana" Ghana Journal of development Studies, Volume 7 No. 1, pp. 1-25.

Alhassan, E. (2011). Gender mainstreaming in basic education in the Northern Region. Legon Journal of Sociology Vol. 4 No. 2, pp. 1-25.

Allen, J. (1994). Basic education for all: The Afghan experience, conceptual framework and strategies. UNESCO. 
Anderson, B. (2002). Girls access to primary education in Pakistan. Palestine: Palestine Press Palestine.

Assie, N. (200o). Educational selection and social inequality in Africa. PhD. Thesis, Chicago Published by University of Chicago Press.

Beijing Platform of Action (1995). Convention for the Elimination of all Forms of Discrimination against women (CEDAW).

Darkwah, A. (2010). Education: pathway to empowerment for Ghanaian women. Institute of Development Studies, Vol. 41 No.2, pp. 28-35.

Delors, Jacques, et al. (1996). Learning: the treasure within. Report to UNESCO of the International Commission on Education for the Twenty-First Century. Paris: UNESCO.

Dolphyne, A. F. (1991). The Emancipation of Women: An African Perspective. Accra: Ghana Universities Press Ghana.

Alhassan, E. (2013). Early Marriage of young females: A panacea to poverty in the Northern Region of Ghana? Journal of Research on Humanities and Social Sciences. Vol. 3 No. 12, pp. 18-30.

El-Sanabary, N. (2001). A Comparative study of the disparities of educational opportunities for girls in Arab countries. Ph.D Dissertation. University of California Berkeley: (Published,) University of California Press.

FAWE (2001). Girls and African education. Kenya: Kenyan Press.

Ghana Statistical Service. (2012). Ghana population census. Accra: Ghana Statistical Service.

Government of Ghana. (1992). The constitution of Ghana, wikipedia.org. Accessed: $21^{\text {st }}$ November 2011.

Government of Ghana. (2010). Ghana Millennium Development Goals Report. Accra: Ministry of Education.

Kane, E. (2004). Girls' education in Africa: what do we know about strategies that work? Washington, DC: The World Bank.

Kendall, N. (2006). Strengthening gender and education programming in the 21st century. Washington, DC: Academy for Educational Development (AED).

Kwesiga, C. (2002). Women Access to higher education in Africa. Kampala. Uganda: Fountain Publishers.

Mathew, J. (2000). Girls' education and empowerment in India. India: New Delhi Press.

MOE (2010). Education sector review (ESR). Accra: Ministry of Education.

Mugenda, M. and Mugenda, G. (1999). Research Methods: Qualitative and Quantitative Approaches. Nairobi: Center for Technology Studies. 
Murshid, T. M. (1996). The sacred and the secular (1871-1977). Dhaka: Dhaka University Press.

Oxfam, G. B. (2005). Beyond the mainstream: education for nomadic and pastoralist girl and boys Oxfam House, Available at http://www.oxfam.org.uk/ Accessed: 1oth September. 2011.

OXFAM. (2005). Beyond access for girls and boys: How to achieve good-quality, gender-equitable education. Education and Gender Equality Series, Programme Insights. London: OXFAM.

Robertson, C. and Berger I. (2004). Women and class in Africa. New York: New York Africana Publishing Company.

Roemer, J. (1998). Equality of opportunity. Cambridge, MA: Harvard University Press.

Schleicher, A. (2007). Student learning outcomes from a gender perspective: What do international assessments tell us? Paper presented at the World Bank's Global Symposium - Education: A Critical Path to Gender Equality and Women's Empowerment, Washington, DC.

Sen, A. (2007). Capability approach and social justice in education. New York: Palgrave Macmillan.

Stromquist, Nelly P. (1995). Gender and basic education in international development Cooperation. UNICEF Staff Working Papers Number 13. New York: UNICEF:

Summers, Lawrence H. (1992). Investing in all people. Educating women in developing Countries. Economic Development Institute of the World Bank. Seminar Paper No. 45 (delivered at the Development Economics Seminar at the World Bank Annual Meeting).

Teresa, H. and Heneveld, W. (1993). Measuring the gap: female education in sub-Saharan Africa. Washington D.C. USA: Africa Technical Department.

UNESCO (2011). Development of education in Africa: a statistical review, seventh conference of ministers of education of African member states between 20-24 ${ }^{\text {th }}$ April 1998. Durban: South Africa.

UNICEF. (2012). The state of education of children from Ghana's rural and urban areas in Ghana. Accra: UNICEF.

United Nations Development Programme (1999). Human development report 1999. New York. Oxford University Press.

UNO. (2002). Early marriage in human right context. Accra: United Nation Special Session on Children. 